\title{
Evaluation of Certain Insecticides against Diamondback Moth (DBM) Plutella xylostella on Cauliflower
}

\author{
Gudivada Harika*, S. Dhurua, M. Suresh and N. Sreesandhya
}

Dept. of Entomology, Agricultural College, Naira, ANGRAU, Andhra Pradesh (532 185), India

\author{
Corresponding Author \\ Gudivada Harika \\ e-mail: harikagudivada@gmail.com
}

\author{
Article History \\ Article ID: AR1940 \\ Received in $13^{\text {th }}$ December, 2018 \\ Received in revised form 23 $3^{\text {rd }}$ February, 2019 \\ Accepted in final form 28 ${ }^{\text {th }}$ February, 2019
}

\begin{abstract}
Studies were carried out in field condition during rabi, from November 2017 to February 2018 at Acharya N. G. Ranga Agricultural University, Agricultural College Farm, Naira, to evaluate the efficacy of certain newer insecticides against diamondback moth (DBM) Plutella xylostella on Cauliflower. The findings of the experiment revealed that all the chemicals evaluated against Diamond back moth larvae were significantly superior to check in protecting cauliflower from Diamond Back Moth at 3 and 7 days after treatment. Among all the tested insecticides, Spinosad 45 SC, Indoxacarb 14.5 SC and Emamectin benzoate 5\% SG proved to be the most effective treatments in reducing the larval population of Diamond Back Moth. During the study Flubendiamide 39.35 SC and Thiodicarb 70 SP were found moderately effective against Diamond back moth. The treatments Lufenuron $5 \mathrm{EC}$ and Acephate 75 WP were found least effective. The highest marketable yield of Cauliflower heads was recorded in Spinosad 45 SC (228.80 q ha- $\left.{ }^{-1}\right)$. It was followed by Indoxacarb 14.5 SC (219.10 q ha $\left.{ }^{-1}\right)$ and emamectin benzoate 5\% SG, which yielded (193.90 q ha ${ }^{-1}$ ) Flubendiamide 39.35 SC, Thiodicarb 70 SP, Lufenuron 5 EC and Acephate 75 WP yielded the lowest marketable yields of $165.90,145.50,120.80$ and $108.00 \mathrm{q} \mathrm{ha}^{-1}$ respectively. The highest Cost Benefit (C:B) ratio of 69.85 was obtained with the treatment Indoxacarb 14.5 SC followed by Emamectin benzoate 5\% SG (60.18), Spinosad 45 SC (30.13) and Flubendiamide 39.35 SC (24.56).
\end{abstract}

Keywords: Plutella xylostella, cauliflower, insecticides, management

\section{Introduction}

Cauliflower (Brassica oleracea var. botrytis Linn.) is an economically important winter vegetable of the several vegetables in the species Brassica oleracea. It contains many nutrients particularly substantial amounts of vitamins (Vit. C, $\mathrm{K}, \mathrm{B}_{6}$ ) and minerals (Mn, P, K). In India, it is cultivated in an area of 4.26 lakh ha. with an average annual production of $8199 \mathrm{mt}$ and productivity of $19.2 \mathrm{mt} \mathrm{ha}^{-1}$ (www.indiastat.com, 201415). The yield of cauliflower is adversely affected by many bottlenecks including insect pest, diseases, environmental stresses, nutritional imbalance etc. Insect pests are of prime importance as they cause serious economic damage to cauliflower crop. Among all, diamondback moth (DBM), which was long considered a relatively insignificant pest, is now becoming a major pest. Cauliflower and cabbage are the most preferred host plants as their fleshy and succulent leaves provide necessary olfactory and gustatory stimuli for successful selection and colonization.

In India, Krishnamoorthy (2004) reported 52\% yield loss on cabbage due to diamondback moth, whereas Lingappa et al. (2006) reported that the yield loss caused by this pest varied from $31-100 \%$. The overall management cost in world for diamondback moth is estimated at US \$ 4-5 billion annually (Zalucki et al., 2012). To control this pest, insecticides have been used indiscriminately, resulting, in the development of resistance to every synthetic insecticide used against it in the field (Talekar et al., 1990). In India, the first report of insecticide resistance development in diamondback moth was around 1966 in Ludhiana, Punjab, against DDT and Parathion (Verma and Sandhu, 1968). After that, the pest has developed resistance to about 82 compounds belonging to different classes of insecticides over 17 countries (Furlong et al., 2013).

The crop production strategies have however experienced a paradigm shift from pest "control" to pest "management". But the management of this pest has become a stupendous task and farmers are compelled to use chemical insecticides in order to cultivate lucratively, as traditional and cultural practices alone cannot give satisfactory control over the pest. Vegetables retain residues of a cocktail of chemicals since these are applied at different stages of crop growth and even just before harvest, resulting in health hazards to the consumers. As exclusion of chemical insecticides is impracticable, it has necessitated the use of alternative 
eco-friendly insecticides for sustainable management of $P$. xylostella which can return diamondback moth to minor pest status by favoring survival of natural enemies and the development of resistance against these traditional insecticides can be easily broken down by using the new group of molecules. Keeping in view of the seriousness of the pest and economic importance of this crop, the present investigation was carried out to evaluate the efficacy of different insecticides viz., Spinosad, Emamectin benzoate, Flubendiamide, Thiodicarb, Indoxacarb, Lufenuron and Acephate under field conditions at Agricultural College Farm, Naira, Andhra Pradesh for their comparative efficacy against P. xylostella on cauliflower, as a part of M. Sc. programme.

\section{Materials and Methods}

The experiment was laid out during 2017-18 in a randomized block design with eight treatments including untreated check replicated thrice with local cauliflower variety Karthika, raised and maintained with standard agronomic practices including normal weeding, irrigation practices, fertilization and sanitation etc. except plant protection measures, followed as per recommended package of practices of Acharya N. G. Ranga Agricultural University.

Individual plots were divided into ridges and furrows with plot size each of $20 \times 10 \mathrm{~m}^{2}$ forming bunds all around. Thirty days old seedlings of cauliflower were transplanted on $27^{\text {th }}$ Nov 2017 at row to row and plant to plant distance of $60 \times 45$ $\mathrm{cm}^{2}$, respectively. When the pest reached its minimum ETL (Economic Threshold Level) the first spraying was done, and further sprayings were given at scheduled spray intervals.

Measured quantity of insecticide was mixed in small quantity of water and later made up with water to required volume of spray fluid. Each plot received 0.6 liters of spray fluid @ 500 I ha-1. The spray fluid was thoroughly stirred before spraying. Spraying was done with a knapsack sprayer in the morning hours to the point of run off for thorough coverage. The sprayer used for spraying was cleaned thoroughly after application of each chemical.

Data on the pest population was recorded at one day before spraying as pretreatment count and $3^{\text {rd }}$ and $7^{\text {th }}$ day after spraying as post treatment counts. The observations were recorded from ten randomly selected plants plot $^{-1}$ leaving the border rows. The data on total number of larvae per head and $\%$ head damage were recorded.

\subsection{Statistical analysis}

The \% population reduction in different treatments over untreated check was calculated by the modified Abbot's formula (Fleming and Ratnakaran, 1985) and the data were subjected to ANOVA. The \% reduction values were duly transformed into corresponding angular values and the data were subjected to statistical analysis (Gomez and Gomez, 1984).
Healthy cauliflower heads were harvested when they reached appropriate marketable size and their weight from each treatment was expressed as marketable yield in $\mathrm{q} \mathrm{ha} \mathrm{h}^{-1}$ and subjected to statistical analysis to test the significance of mean yield in different treatments. The \% increase in yield of cauliflower heads over control in each treatment was calculated by using the formula,

$\%$ increase of yield over control =(Yield in treatment-Yield in untreated control)/yield in untreated control $\times 100$

Later the yield data were subjected to statistical analysis. To determine the most effective and economic treatment, Cost Benefit ratio (CBR) of different treatments worked out by taking into consideration the cost of insecticides used, labor cost and prevailing market price of cauliflower.

\section{Results and Discussion}

The population of diamondback moth recorded before spraying was found to be non-significant among the different treatments, which indicated that the infestation of diamondback moth was homogenous.

\subsection{Overall pooled efficacy of first spray}

The mean data after first spray (Table 1 ) recorded at 3 and 7 DAT showed that Spinosad 45 SC was found to be the best and most effective treatment with a reduction of $86.35 \%$ over untreated control and significantly superior over all other treatments. The treatment indoxacarb 14.5 SC (78.15\%) was also found to be good with more than $78 \%$ reduction in population of $P$. xylostella over control and was also significantly superior to remaining treatments. The next best treatment was emamectin benzoate 5\% SG with $68.20 \%$ reduction of larval population of superior over other remaining treatments. Flubendiamide 39.35 SC, thiodicarb $70 \mathrm{SP}$, lufenuron $5 \mathrm{EC}$ and acephate 75 WP were found to be significantly the least effective treatments being on par with a reduction of $59.40,52.70,45.15$, and $36.45 \%$ over untreated control.

\subsection{Overall pooled efficacy of second spray}

The overall efficacy of the post treatment observations recorded at 3 and 7 DAT after second spray (Table 1) showed that spinosad 45 SC, indoxacarb 14.5 SC and emamectin benzoate 5\% SG were found to be the best and the most effective being on par with 83.35, 76.65 and $70.15 \%$ reduction in population over untreated control and were significantly superior to all other treatments. The treatments flubendiamide 39.35 SC (56.95\%) and thiodicarb $70 \mathrm{SP}$ (49.40\%) were also found to be good with more than $49 \%$ reduction in population of $P$. xylostella over control and was also significantly superior to remaining treatments.

Among the treatments lufenuron 5 EC and acephate 75 WP were found to be on par with 47.30 and $38.50 \%$ reduction in population over untreated control and were significantly the least effective treatments of diamondback moth 


\begin{tabular}{|c|c|c|c|c|c|c|c|c|}
\hline \multirow[t]{3}{*}{ Treatments } & \multicolumn{4}{|c|}{ (First spray) } & \multicolumn{4}{|c|}{ (Second spray) } \\
\hline & \multirow[t]{2}{*}{$\begin{array}{l}\text { Pretreat- } \\
\text { ment } \\
\text { count }\end{array}$} & \multicolumn{2}{|c|}{$\begin{array}{l}\text { Mean per cent } \\
\text { population reduction } \\
\text { over untreated check }\end{array}$} & \multirow[t]{2}{*}{$\begin{array}{l}\text { Overall } \\
\text { mean } \\
\text { efficacy }\end{array}$} & \multirow[t]{2}{*}{$\begin{array}{l}\text { Pretreat- } \\
\text { ment } \\
\text { count }\end{array}$} & \multicolumn{2}{|c|}{$\begin{array}{l}\text { Mean per cent popu- } \\
\text { lation reduction over } \\
\text { untreated check }\end{array}$} & \multirow[t]{2}{*}{$\begin{array}{l}\text { Overall } \\
\text { mean } \\
\text { efficacy }\end{array}$} \\
\hline & & 3 DAT & 7 DAT & & & 3 DAT & 7 DAT & \\
\hline $\begin{array}{l}\text { Spinosad 45 SC @ } 0.3 \mathrm{ml} \\
\mathrm{l}^{-1}\end{array}$ & $\begin{array}{c}50.70 \\
(45.36)^{*}\end{array}$ & $\begin{array}{c}87.80 \\
(69.65)^{\mathrm{a}}\end{array}$ & $\begin{array}{c}84.90 \\
(67.32)^{\mathrm{a}}\end{array}$ & $\begin{array}{c}86.35 \\
(68.44)^{\mathrm{a}}\end{array}$ & $\begin{array}{c}44.0 \\
(41.52)^{*}\end{array}$ & $\begin{array}{c}84.60 \\
(67.12)^{\mathrm{a}}\end{array}$ & $\begin{array}{c}82.10 \\
(64.96)^{\mathrm{a}}\end{array}$ & $\begin{array}{l}83.35 \\
(66.03)^{a}\end{array}$ \\
\hline $\begin{array}{l}\text { Emamectin benzoate } 5 \% \\
\text { SG @ } 0.4 \mathrm{~g} \mathrm{l}^{-1}\end{array}$ & $\begin{array}{l}47.70 \\
(43.64)\end{array}$ & $\begin{array}{c}69.90 \\
(56.74)^{\mathrm{c}}\end{array}$ & $\begin{array}{c}66.50 \\
(54.60)^{\mathrm{c}}\end{array}$ & $\begin{array}{c}68.20 \\
(55.86)^{c}\end{array}$ & $\begin{array}{c}39.0 \\
(38.61)\end{array}$ & $\begin{array}{c}72.50 \\
(58.39)^{\mathrm{b}}\end{array}$ & $\begin{array}{c}67.80 \\
(55.46)^{\mathrm{a}}\end{array}$ & $\begin{array}{c}70.15 \\
(57.10)^{\mathrm{a}}\end{array}$ \\
\hline $\begin{array}{l}\text { Flubendiamide } 39.35 \mathrm{SC} \\
@ 0.2 \mathrm{ml} \mathrm{l}^{-1}\end{array}$ & $\begin{array}{c}49.70 \\
(44.79)\end{array}$ & $\begin{array}{c}61.80 \\
(51.84)^{\mathrm{d}}\end{array}$ & $\begin{array}{c}57.00 \\
(49.01)^{\mathrm{d}}\end{array}$ & $\begin{array}{c}59.40 \\
(50.48)^{\mathrm{d}}\end{array}$ & $\begin{array}{c}40.0 \\
(39.21)\end{array}$ & $\begin{array}{c}61.40 \\
(51.57)^{c}\end{array}$ & $\begin{array}{c}52.50 \\
(46.40)^{\mathrm{b}}\end{array}$ & $\begin{array}{c}56.95 \\
(48.73)^{b}\end{array}$ \\
\hline Thiodicarb 70 SP @ $1 \mathrm{~g} \mathrm{I}^{-1}$ & $\begin{array}{l}51.70 \\
(45.93)\end{array}$ & $\begin{array}{c}55.10 \\
(47.90)^{\mathrm{e}}\end{array}$ & $\begin{array}{c}50.30 \\
(45.17)^{\mathrm{e}}\end{array}$ & $\begin{array}{c}52.70 \\
(46.43)^{d}\end{array}$ & $\begin{array}{c}42.7 \\
(40.76)\end{array}$ & $\begin{array}{c}53.70 \\
(47.07)^{d}\end{array}$ & $\begin{array}{c}45.10 \\
(42.14)^{c}\end{array}$ & $\begin{array}{c}49.40 \\
(44.71)^{c}\end{array}$ \\
\hline $\begin{array}{l}\text { Indoxacarb 14.5 SC @ } 1 \\
\mathrm{ml} \mathrm{l}^{-1}\end{array}$ & $\begin{array}{c}54.30 \\
(47.47)\end{array}$ & $\begin{array}{c}79.30 \\
(63.00)^{\mathrm{b}}\end{array}$ & $\begin{array}{l}77.00 \\
(61.36)^{\mathrm{b}}\end{array}$ & $\begin{array}{c}78.15 \\
(62.37)^{\mathrm{b}}\end{array}$ & $\begin{array}{c}44.0 \\
(41.51)\end{array}$ & $\begin{array}{c}77.70 \\
(61.89)^{\mathrm{a}}\end{array}$ & $\begin{array}{c}75.60 \\
(60.49)^{\mathrm{a}}\end{array}$ & $\begin{array}{c}76.65 \\
(61.00)^{\mathrm{a}}\end{array}$ \\
\hline $\begin{array}{l}\text { Lufenuron } 5 \text { EC @ } 0.8 \mathrm{ml} \\
\mathrm{l}^{-1}\end{array}$ & $\begin{array}{c}50.70 \\
(45.36)\end{array}$ & $\begin{array}{c}49.20 \\
(44.51)^{f}\end{array}$ & $\begin{array}{c}41.10 \\
(39.84)^{f}\end{array}$ & $\begin{array}{c}45.15 \\
(42.42)^{d}\end{array}$ & $\begin{array}{c}37.0 \\
(37.44)\end{array}$ & $\begin{array}{c}47.30 \\
(43.42)^{\mathrm{e}}\end{array}$ & $\begin{array}{c}37.70 \\
(37.86)^{d}\end{array}$ & $\begin{array}{c}42.50 \\
(40.69)^{d}\end{array}$ \\
\hline $\begin{array}{l}\text { Acephate } 75 \text { WP @ } 1.5 \\
\mathrm{~g} \mathrm{|}^{-1}\end{array}$ & $\begin{array}{c}48.70 \\
(44.21)\end{array}$ & $\begin{array}{c}41.20 \\
(39.90)^{\mathrm{g}}\end{array}$ & $\begin{array}{c}31.70 \\
(34.23)^{\mathrm{g}}\end{array}$ & $\begin{array}{c}36.45 \\
(37.17)^{d}\end{array}$ & $\begin{array}{c}40.0 \\
(39.21)\end{array}$ & $\begin{array}{c}38.50 \\
(38.33)^{\mathrm{e}}\end{array}$ & $\begin{array}{c}29.30 \\
(32.75)^{\mathrm{e}}\end{array}$ & $\begin{array}{c}33.90 \\
(35.37)^{d}\end{array}$ \\
\hline Untreated check (control) & $\begin{array}{c}51.70 \\
(45.93)\end{array}$ & $\begin{array}{c}0.0 \\
(0.00)\end{array}$ & $\begin{array}{c}0.0 \\
(0.00)\end{array}$ & $\begin{array}{c}0.0 \\
(0.00)\end{array}$ & $\begin{array}{c}39.7 \\
(39.01)\end{array}$ & $\begin{array}{c}0.0 \\
(0.00)\end{array}$ & $\begin{array}{c}0.0 \\
(0.00)\end{array}$ & $\begin{array}{c}0.0 \\
(0.00)\end{array}$ \\
\hline F test & NS & Sig. & Sig. & Sig. & NS & Sig. & Sig. & Sig. \\
\hline SEm \pm & & 1.46 & 1.48 & 1.47 & & 1.68 & 1.50 & 1.59 \\
\hline $\mathrm{CD}(p=0.05)$ & & 4.49 & 4.54 & 4.51 & & 5.17 & 4.60 & 4.88 \\
\hline
\end{tabular}

*Values in parentheses are angular transformed values; Sig.: Significant; NS: Non-Significant; DAT: Days after treatment; Values with same alphabet in each column do not vary significantly from each other

population by recording less than $39 \%$ reduction. However, all the treatments were effective and significantly superior in reducing the larval population of $P$. xylostella over untreated control.

\subsection{Overall Mean efficacy of both sprays}

The overall efficacy of the post treatment observations recorded at 3 and 7 DAT of two sprays (Figure 1 ) showed that spinosad $45 \mathrm{SC}$, indoxacarb $14.5 \mathrm{SC}$ and emamectin benzoate $5 \%$ SG were found to be the best and the most effective being on par with $84.85,77.40$ and $69.17 \%$ reduction in population over untreated control and were significantly superior to all other treatments. A voluminous research data to confirm the results of spinosad is available (Dey and Somchoudhury, 2001, Mahalakshmi et al., 2002, Prithwiraj and Chatterjee, 2003, Tambe and Mote, 2003, Syed et al., 2004, Walunj and Pawar, 2004, Wemin and Wesis, 2006, Jasmine et al., 2007, Kumar et al., 2007c, Sable et al., 2007, Meena and Singh, 2013, Vaseem et al., 2014, Stanikzi and Thakur, 2016, Reddy et al., 2017, Sharma et al., 2017a, Venugopal et al., 2017 and Yadav et al., 2017).

The results of indoxacarb are in conformity with the results of

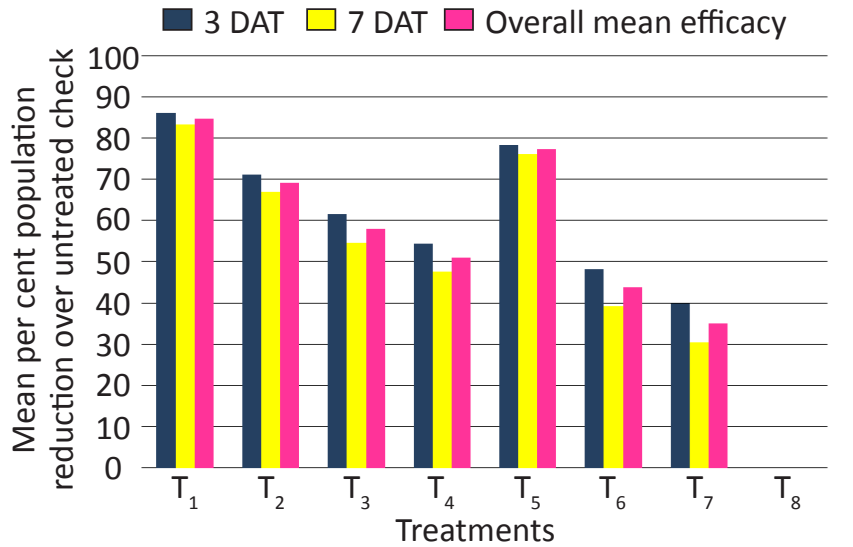

Figure 1: Cumulative efficacy of the treatments against $P$. xylostella on cauliflower during rabi, 2017-18

Liu et al. (2003), Martinelli et al. (2003), Sannaveerappanavar et al. (2003), Kumar et al. (2007a), Sable et al., 2007), Chakraborty and Somchoudhury (2011), Ismail et al. (2012), Meena and Singh (2013), Karthik et al. (2015), Patra et al. (2016), Stanikzi and Thakur (2016), Patra et al. (2017), Selvaraj and Kennedy (2017), Sharma et al. (2017a) and Yadav et al. 
(2017) against diamondback moth. The results of emamectin benzoate are in conformity with the results of Suganyakanna (2003), Suganyakanna et al. (2005), Kumar and Devappa (2006), Matthew (2007), Shivalingaswamy et al. (2008), Kailash et al. (2016), Stanikzi and Thakur (2016), Reddy et al. (2017) and Sharma et al. (2017a).

The next effective treatments that have shown a moderate degree of efficacy were flubendiamide 39.35 SC (58.17\%) and thiodicarb 70 SP (51.05\%) with more than $52 \%$ reduction in population of $P$. xylostella over control and were also significantly superior to remaining treatments. Similar results regarding the efficacy of flubendiamide obtained in the present investigation also corroborating with the earlier findings of several researchers (Kumar et al., 2007b, Selvaraj and Kennedy, 2017 and Sharma et al., 2017a) conforming the outcome of the present study. The treatment of thiodicarb existed in moderately effective group of insecticides in the present investigation which corroborate with the findings of Katra and Sharma (2000), Vastrad et al. (2002) and Sable et al. (2007). However, the present results do not corroborate with that of Mandal and Mandal (2009) who reported thiodicarb 75 SP as less effective insecticide against $P$. xylostella on cauliflower. The difference in efficacy of insecticides may probably be due to the pressure of pest population and doses used for controlling the pest.

Among the treatments lufenuron 5 EC and acephate 75 WP were significantly the least effective treatments being on par with 43.82 and $35.17 \%$ reduction in diamondback moth population over untreated control. These results regarding the efficacy of lufenuron are in concordant with Senguttuvan and Kuttalam (2013) and Sharma et al. (2017b) against DBM population but do not corroborate with the findings of Vastrad et al. (2002) and Kulye et al. (2007) who reported lufenuron as the most effective insecticide against $P$. xylostella population. The performance of acephate is in accordance with Ojha et al. (2004a), Mandal and Mandal (2009) and Sharma et al. (2017a). The present results however, gets partial support from the results of Selvaraj and Kennedy (2017), who found acephate as a moderately effective insecticide against DBM population. However, all the treatments were effective and significantly superior in reducing the larval population of $P$. xylostella over untreated control.

Among the treatments lufenuron 5 EC and acephate 75 WP were significantly the least effective treatments being on par with 43.82 and $35.17 \%$ reduction in diamondback moth population over untreated control. These results regarding the efficacy of lufenuron are in concordant with Senguttuvan and Kuttalam (2013) and Sharma et al. (2017b) against DBM population but do not corroborate with the findings of Vastrad et al. (2002) and Kulye et al. (2007) who reported lufenuron as the most effective insecticide against $P$. xylostella population. The performance of acephate is in accordance with Ojha et al. (2004a), Mandal and Mandal (2009) and Sharma et al. (2017a). The present results however, gets partial support from the results of Selvaraj and Kennedy (2017), who found acephate as a moderately effective insecticide against DBM population. However, all the treatments were effective and significantly superior in reducing the larval population of $P$. xylostella over untreated control.

\section{4. \% head damage at the time of curd harvest}

$\%$ head damage on cauliflower plants at the time of curd harvest indicated that the lowest \% of head damage of 8.48 was recorded in the treatment spinosad 45 SC followed by indoxacarb 14.5 SC (12.36), emamectin benzoate 5\% SG (22.44), flubendiamide 39.35 SC (33.64), thiodicarb 70 SP (41.80), lufenuron 5 EC (51.68) and acephate 75 WP (56.80). However, all the treatments were significantly superior to untreated check which recorded the highest \% head damage of 64.32 in terms of \% head damage.

\subsection{Effect of insecticidal treatments on curd yield during Rabi} 2017-18

Since all the agronomic practices except the plant protection treatments remained the same, the variation in yield was attributed to the effect of the treatments in reducing yield losses by insect pests. During harvest, healthy heads without any pest infestation were separated and weighed separately, which was treated as marketable yield.

The data on yield recorded in different insecticidal treatments is presented in Table 2 revealed that spinosad 45 SC, as a result of its higher efficacy in reducing the pest incidence in terms of \% larval population, it recorded highest yield of $228.80 \mathrm{q} \mathrm{ha}^{-1}$ with $156.50 \%$ higher yield over untreated control and these results are in conformity with the earlier results of Tambe and Mote (2003), Sable et al. (2007), Meena and Singh (2013), Vaseem et al. (2014) and Sawant and Patil (2017) who recorded $222 \mathrm{q} \mathrm{ha}^{-1}, 214.42 \mathrm{q} \mathrm{ha}^{-1}, 233.5 \mathrm{q} \mathrm{ha}^{-1}, 224.74$ q ha-1 and $236.91 \mathrm{q} \mathrm{ha}^{-1}$ of marketable cauliflower heads, respectively with spinosad. It was followed by indoxacarb 14.5 SC (219.10 q ha-1) with $145.62 \%$ higher yield over untreated control which is in accordance with reports of Sable et al., 2007 (206.94 q ha-1) and Meena and Singh, 2013 (226.8 q ha-1) who reported higher yields of cauliflower with indoxacarb. Emamectin benzoate 5\% SG also recorded good yields 193.90 q ha ${ }^{-1}$ with $117.37 \%$ increase in yield over control. Regarding the efficacy of emamectin benzoate in recording good yields is in conformity with Kumar and Devappa (2006) who reported higher yield of cabbage heads 113.23 and $95.80 \mathrm{~kg} \mathrm{plot}^{-1}$ with emamectin benzoate @ 150 g a.i. ha-1 and 200 g a.i. ha-1, respectively.

The descending order of efficacy among the rest of the treatments to visualize through curd yield was flubendiamide 39.35 SC (165.90 q ha $\left.{ }^{-1}\right)$, thiodicarb 70 SP (145.50 q ha-1), lufenuron 5.40 EC (120.80 q ha $\left.{ }^{-1}\right)$ and acephate 75 WP (108.00 $q$ ha $^{-1}$ ) recorded $85.98,63.11,35.42$ and $21.07 \%$ increase in yield over control, respectively. Regarding the curd yield in treatment flubendiamide, the present results obtain partial conformity with Sawant and Patil (2017) who recorded 
Table 2: Effect of the treatments on the curd yield of cauliflower during rabi, 2017-18

\begin{tabular}{|c|c|c|c|}
\hline Treatments & $\begin{array}{c}\text { Mean } \\
\text { curd yield } \\
\left(\mathrm{kg} \mathrm{plot}^{-1}\right)\end{array}$ & $\begin{array}{l}\text { Curd } \\
\text { yield } \\
(\mathrm{q} \mathrm{ha-1})\end{array}$ & $\begin{array}{l}\% \text { increase } \\
\text { over control }\end{array}$ \\
\hline $\begin{array}{l}\text { Spinosad 45 SC @ } \\
0.3 \mathrm{ml} \mathrm{l}^{-1}\end{array}$ & 45.8 & 228.80 & 156.50 \\
\hline $\begin{array}{l}\text { Emamectin benzo- } \\
\text { ate } 5 \% \mathrm{SG} @ 0.4 \mathrm{~g} \mathrm{l}^{-1}\end{array}$ & 38.8 & 193.90 & 117.37 \\
\hline $\begin{array}{l}\text { Flubendiamide } \\
39.35 \mathrm{SC} @ 0.2 \mathrm{ml} \mathrm{l}^{-1}\end{array}$ & 33.2 & 165.90 & 85.98 \\
\hline $\begin{array}{l}\text { Thiodicarb } 70 \text { SP @ } \\
1 \mathrm{gl}^{-1}\end{array}$ & 29.1 & 145.50 & 63.11 \\
\hline $\begin{array}{l}\text { Indoxacarb } 14.5 \mathrm{SC} \\
@ 1 \mathrm{ml} \mathrm{l}^{-1}\end{array}$ & 43.8 & 219.10 & 145.62 \\
\hline $\begin{array}{l}\text { Lufenuron } 5 \text { EC @ } \\
0.8 \mathrm{ml} \mathrm{l}^{-1}\end{array}$ & 24.2 & 120.80 & 35.42 \\
\hline $\begin{array}{l}\text { Acephate } 75 \text { WP @ } \\
1.5 \mathrm{~g} \mathrm{l}^{-1}\end{array}$ & 21.6 & 108.00 & 21.07 \\
\hline $\begin{array}{l}\text { Untreated check } \\
\text { (control) }\end{array}$ & 17.8 & 89.20 & 0.00 \\
\hline F test & Sig. & Sig. & \\
\hline SEm \pm & 1.4 & 6.8 & \\
\hline $\mathrm{CD}(p=0.05)$ & 4.1 & 20.7 & \\
\hline
\end{tabular}

Sale price of cauliflower - ₹ 900/q

$228.49 \mathrm{q} \mathrm{ha}^{-1}$ marketable cabbage heads with flubendiamide $18.24 \mathrm{~g} \mathrm{a.i} \mathrm{ha}^{-1}$. The significant increase in the curd yield in the treatment thiodicarb (145.50 q ha-1) over control was obtained in present findings and gets partially support from the work of Sable et al. (2007) who recorded $128.46 \mathrm{q} \mathrm{ha}^{-1}$. The present results do not corroborate with the results of Vastrad et al. (2002) and Mandal and Mandal (2009) who recorded the curd yield as $340 \mathrm{q} \mathrm{ha}^{-1}$ and $189.52 \mathrm{q} \mathrm{ha}^{-1}$, respectively. Regarding the curd yield in treatment flubendiamide, the present results obtain partial conformity with the work of Senguttuvan and Kuttalam (2013). The treatment acephate recorded lowest curd yield in the present investigation and the results partly get support from the work of Ojha et al. (2004a) and Mandal and Mandal (2009) who reported that acephate was least effective against $P$. xylostella population with lower curd yields.

3.6. Cost benefit ratio (CBR) of different treatments during rabi 2017-18

The Cost Benefit ratios (CBR) among various insecticidal treatments varied between 1: 69.85 to 1:12.95. Maximum (1: 69.85) CBR was recorded with indoxacarb 14.5 SC followed by emamectin benzoate 5\% SG (60.18), spinosad 45 SC (30.13), flubendiamide 39.35 SC (24.56), thiodicarb 70 SP (21.03), lufenuron 5.40 EC (13.24) and acephate 75 WP (12.95). The cost effectiveness of indoxacarb $14.5 \mathrm{SC}$ might be due to the lower dosage of the chemical against DBM larval population coupled with low market price of the treatment.

\section{Conclusion}

Spinosad 45 SC, indoxacarb 14.5 SC and emamectin benzoate $5 \%$ SG proved to be the most effective treatments in reducing DBM larval population. The highest yield was recorded in spinosad 45 SC (228.80 q ha-1) followed by indoxacarb 14.5 SC $\left(219.10 \mathrm{q} \mathrm{ha}^{-1}\right)$. The C:B ratio of 69.85 was obtained from indoxacarb 14.5 SC followed by emamectin benzoate 5\% SG (60.18) and spinosad 45 SC (30.13).

\section{References}

Chakraborty, G., Somchoudhury, A.K., 2011. Effect of pyridalyl against Plutella xylostella (L.) on cabbage and natural enemies. Journal of Crop and Weed 7(1), 142-145.

Dey, P.K., Somchoudhury, A.K., 2001. Evaluation of spinosyns $A+D$ (spinosad $48 \mathrm{SC}$ ) against lepidopteran pest complex of cabbage and its effect on natural enemies of diamondback moth under field conditions of West Bengal. Pestology 25(1), 54-58.

Fleming, R., Ratnakaran, A., 1985. Evaluation single treatment data using Abbot's formula with modification. Journal of Economic Entomology 78, 1179.

Furlong, M.J., Wright, D.J., Dosdall, L.M., 2013. Diamondback moth ecology and management: Problems, progress and prospects. Annual Review of Entomology 58, 517-541.

Gomez, K.A., Gomez, A.A., 1984. Statistical procedure for agricultural research. John Wiley Sons, Newyork. 68.

Indiastat, 2014-15. Available from http://www.indiastat.com. Ministry of agriculture, Government of India. Accessed on 16-09-2017.

Ismail, F., Norazam, M.T.M., Rasdi, Z.M., 2012. Toxicity of selected insecticides (spinosad, indoxacarb and abamectin) against the diamondback moth (Plutella xylostella L.) on cabbage. Asian Journal of Agriculture and Rural Development 2(1), 17-26.

Jasmine, S.R., Kuttalam, S., Stanley, J., 2007. Bio-efficacy of abamectin against diamondback moth, (Plutella xylostella L.). Indian Journal of Plant Protection 35(1), 60-63.

Kailash, C., Bhowmick, A.K., Marabi, R.S., Das, S.B., Kailash, C.M., 2016. Evaluation of emamectin benzoate against diamondback moth in cabbage. International Journal of Agriculture Sciences 8(51), 2375-2377.

Karthik, P., Venugopal, S., Thangavel, K., Sharmila, U., Senthil, K., Kuttalam, S., 2015. Field efficacy and residues of diafenthiuron 50 WP in cabbage. Pestology 39(5), 41-43.

Katra, V.K., Sharma, S.S., 2000. Comparative efficacy of thiodicarb and some other newly introduced insecticides against diamondback moth. Haryana Journal of Horticultural Sciences 29(1-2), 134-35. 
Krishnamoorthy, A., 2004. Biological control of diamondback moth Plutella xylostella (L.), an Indian scenario with reference to past and future strategies: In Proceedings of the International Symposium (Kirk, A.A., Bordat, D. (Eds.), 21-24 October 2002, Montpellier, France, CIRAD, 204-211.

Kulye, M.S., Gondhalekar, A.D., Chaudhari, C.S., Chadele, A.G., 2007. Efficacy of some moult inhibiting insecticides against Plutella xylostella on cabbage. Annals of Plant Protection Science, 15(2), 469-470.

Kumar, A., Satpathy, S., Shivalingaswamy, T.M., Rai, M. 2007a. Field efficacy of indoxacarb against diamondback moth, Plutella xylostella L. on cabbage. Pestology 31(4), 41-43.

Kumar, B.V., Srinivasan, T., Kumaran, N., Kuttalam, S., 2007b. Evaluation of flubendiamide 480 SC against diamondback moth (Plutella xylostella L.) in cabbage. Pestology 31(11), 48-51.

Kumar, P., Devappa, V., 2006. Bio-efficacy of emamectin benzoate 5\% SG (Proclaim) against diamondback moth in cabbage, Pestology 30(2), 23-25.

Kumar, P., Prasad, C.S., Patel, L.N., 2007c. Efficacy and economics of insecticides and bio-pesticides against Plutella xylostella (L.) on cabbage. Annals of Plant Protection Science, 15(2), 342-344.

Lingappa, S.K., Basavanagoud, K.A., Kulkarni, K.A., Patil, S., Kambrekar, D.N., 2006. Threat to vegetable production by diamondback moth and its management strategies. Disease Management in Fruits and Vegetables, 1, 357-396.

Liu, T.X., Sparks, A.N., Chen, V., 2003. Toxicity, persistence and Plutella xylostella (Lepidoptera: Plutellidae) immature in cabbage. International Journal of Pest Management, 49(3), 235-241.

Mahalakshmi, M.S., Rao, P.A., Ramachandra, R.G., 2002. Efficacy of some newer insecticide against Plutella xylostella L. infesting mustard. The Andhra Agricultural Journal 49(1\&2), 65-68.

Mandal, S.K., Mandal, R.K., 2009. Comparative efficacy of insecticides against Plutella xylostella (L.) on cauliflower. Annals of Plant Protection Science 2, 283-287.

Martinelli, S., Montagna, M.A., Picinato, N.C., Silva, F.M., Fernandes, O.A., 2003. Efficacy of indoxacarb in the control of vegetable pests. Horticultura brasileira 21(3), 501-505.

Matthew, H., 2007. Evaluation of chlorantraniliprole, flubendiamide, indoxacarb, metaflumizone and pyridalyl for diamondback moth, Plutella xylostella (L.) in Hawaii. ESA Annual Meeting, December, 9-19.

Meena, S.C., Singh, V., 2013. Bio-efficacy of different insecticides/biopesticides against Plutella xylostella in cabbage. Indian Journal of Plant Protection 41(4), 290-295.

Ojha, P.K., Singh, I.P., Pandey, N.K., 2004a. Comparative efficacy of some new insecticides against insect-pests of cauliflower under Agro-climatic Zone-1 of Bihar. Pestology 28(4), 36-39.

Patra, S., Das, B.C., Sarkar, S., Samanta, A., 2016. Efficacy of newer insecticides against major lepidopteran pests of cabbage. Research on Crops 17(1), 144-150.

Patra, S., Dhote, V.W., Sarkar, S., Samanta, A., 2017. Evaluation of novel insecticides against diamondback moth and natural enemies in cabbage ecosystem. Journal of Environmental Biology 38, 1383-1389.

Prithwiraj, P., Chatterjee, M.L., 2003. Efficacy of some new insecticides in the management of diamondback moth (Plutella xylostella L.) in cabbage. Indian Journal of Plant Protection. 31(2), 42-44.

Reddy, A., Shashi, V., Rao, C.H.S., Aruna, M., 2017. Bioefficacy of insecticides against diamondback moth Plutella xylostella (L.) in cabbage (Brassica oleracea var. capitata). International Journal of Current Microbiology and Applied Sciences 6(6), 1121-1125.

Sable, Y.R., Sarkate, M.B., Sarode, S.V., Sangale, P.O., Shinde, B.D., 2007. Efficacy of newer molecules against Plutella xylostella L. Pest Management in Horticultural Ecosystems 13(2), 139-145.

Sannaveerappanavar, V.T., Kamala, N.V., Murthy, M.S., Chandrashekara, K., 2003. Proceeding of the national symposium on frontier area of entomological research, Indian Agriculture Research Institute, New Delhi, 88-89.

Sawant, C.G., Patil, C.S., 2017. Bio-efficacy of newer insecticides against diamondback moth (Plutella xylostella L.) in cabbage. International Journal of Bioengineering and Life Sciences 11(10), 51-54.

Selvaraj, C., Kennedy, J.S., 2017. Bio-efficacy of some new generation insecticides on Plutella xylostella $\mathrm{L}$. in and toxicity on two natural enemies. International Journal of Agriculture Sciences 9(3), 3680-3682.

Senguttuvan, K., Kuttalam, S., 2013. Management of diamondback moth (Plutella xylostella L.) in cabbage at tropical and temperate regions of Tamil Nadu with chitin synthesis inhibitor. Madras Agriculture Journal 100(1-3), 206-209.

Sharma, P., Kumawat, K.C., Khinchi, S.K., Kumar, V., Prasad, B., 2017a. Bio efficacy of different insecticides against diamondback moth. International Journal of Chemical Studies 5(3), 891-893.

Sharma, S., Ahmad, H., Sharma, D., Ganai, S.A., Kour, R., Khaliq, N., Norboo, T., 2017b. Studies on seasonal incidence and field efficacy of insect growth regulators against diamondback moth, Plutella xylostella (L.) infesting cabbage, Brassica oleracea var. capitata (L.). Journal of Entomology and Zoology Studies 5(5), 1921-1925.

Shivalingaswamy, T.M., Kumar, A., Satpathy, S., Rai, A.B., 2008. Efficacy of emamectin benzoate in the management of vegetable pests. Progressive Horticulture 40(2), 193-197.

Stanikzi, R., Thakur, S., 2016. Efficacy of chemical insecticides and botanicals in the management of diamondback moth 
(Plutella xylostella) in cabbage (Brassica oleracea var. capitata L.). International Journal of Multidisciplinary Research and Development 3(6), 101-104.

Suganyakanna, S., 2003. Bio-efficacy and selective toxicity of emamectin 5 SG against diamondback moth on cabbage and tomato fruit borer. M.Sc. (Ag.) Thesis submitted to Tamil Nadu Agricultural University, Coimbatore, India, 71.

Suganyakanna, S., Chandrasekaran, S., Regupathy, A., Lavanya, D., 2005. Emamectin 5 SG (Proclaim) - A newer insecticide for diamondback moth Plutella xylostella (L.) management in cabbage. Pestology 29(3), 24-27.

Syed, T.S., Abro, G.H., Ahmed, A., 2004. Efficacy of different insecticides against (Plutella xylostella $\mathrm{L}$.) under field conditions. Pakistan Journal of Biological Sciences 7(1), 10-13.

Talekar, N.S., Yang, J.C., Lee, S.T., 1990. Compilers of annotated bibliography of diamondback moth. Asian Vegetable Research and Development Centre, Shanhus, Taiwan 2, 199.

Tambe, A.B., Mote, U.N., 2003. Effectiveness of new molecule, spinosad 2.5 SC against diamondback moth (Plutella xylostella L.) on cabbage. Journal of Applied Zoological Researches 14(1), 44-45.

Vaseem, M., Singh, H., Kumar, K., Ali, M., 2014. Efficacy of newer insecticides against diamondback moth (Plutella xylostella Linn) on cabbage under polyhouse condition. Journal of Experimental Zoology India 17(2), 487-489.

Vastrad, A.S., Lingappa, S., Basavanagoud, K., 2002. Management of insecticide resistant populations of diamondback moth, Plutella xylostella (L.) (Yponomeutidae: Lepidoptera). Pest Management in Horticultural Ecosystems 9(1), 33-40.

Venugopal, U., Kumar, A., Kota, S., Ramya, V., 2017. Efficacy of certain insecticides against diamondback moth (Plutella xylostella L.) on cabbage (Brassica oleracea var. capitata L.). Agriculture Update 12 (TECHSEAR-6), 1612-1616.

Verma, A.M., Sandhu, G.S., 1968. Chemical control of diamondback moth, Plutella maculipennis. Journal of Research Punjab Agriculture University 5, 420-423.

Walunj, A.R., Pawar, S.A., 2004. Evaluation of spinosad against diamondback moth (Plutella xylostella L.) on cabbage. Tests of Agrochemicals and Cultivars 25, 4-5.

Wemin, J., Wesis, P., 2006. Evaluation of four insecticides as part of an integrated pest management strategy for diamondback moth, Plutella xylostella L. in the highlands of Popu, New Guinea. ACIAR Technical Report Series 62, 49-56.

Yadav, S.K., Raju, S.V.S., Yadav, M.K., Srivastava, A.K., Dwivedi, P.K., 2017. Bio-efficacy of new insecticidal molecules against the diamondback moth (Plutella xylostella L.) on cauliflower. Journal of Experimental Zoology India 20(1), 465-469.

Zalucki, M.P., Shabbir, A., Silva, R., Adamson, D., Shu-Sheng, L., Furlong, M.J., 2012. Estimating the economic cost of one of the world's major insect pest, Plutella xylostella (Lepidoptera: Plutellidae). Journal of Economic Entomology 105, 1115-1129. 